Article

\title{
Sustainable Development Goals and Investment Strategies: The Profitability of Using Five-Factor Fama-French Alphas
}

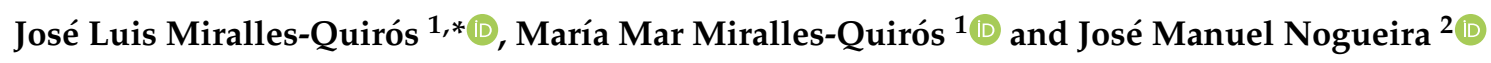 \\ 1 Department of Financial Economics, University of Extremadura, 06006 Badajoz, Spain; marmiralles@unex.es \\ 2 Department of Financial Economics, Polytechnic Institute of Tomar, 2300-313 Tomar, Portugal; \\ nogueira@ipt.pt \\ * Correspondence: miralles@unex.es; Tel.: +34-924-289-510
}

Received: 20 January 2020; Accepted: 28 February 2020; Published: 29 February 2020

check for updates

\begin{abstract}
This study focuses on assets related to Sustainable Development Goals (SDGs), which are the most recent aspect of the Socially Responsible Investment framework and have caught the attention of investors due to their investment opportunities as well as the global challenges that can be achieved. The profitability of developing an investment strategy is shown based on the value of the alphas obtained from the estimation of the Fama-French five-factor model when compared to an equally weighted portfolio, even when transaction costs are taken into consideration. In addition, it is proven that investors should focus their investments on two main SDGs: Good health and well-being (Goal 3) and Industry, innovation and infrastructure (Goal 9).
\end{abstract}

Keywords: socially responsible investment; sustainable development goals; exchange traded funds; multi-factor models; portfolio performance

\section{Introduction}

The United Nations' Sustainability Development Goals (SDGs, hereafter) launched in September 2015 are a set of 17 goals focused on the way of solving some of the most urgent problems the world is facing: poverty, clean water, clean energy, decent work and economic growth and climate action, among others. These SDGs make up the globally agreed sustainability agenda to be reached by 2030 [1]. Both the public and the private sectors are needed to accelerate the transition to a sustainable economy and achieve these general goals. In this context, investors have an important role in promoting the reorientation of financial markets to support these goals by understanding their growth potential and their risk for example by allocating their capital into investments which support the SDGs. Therefore, investors could improve their financial performance by acting in such a way as to encourage sustainable economies and markets, in accordance with the Principles of Responsible Investment (PRI) developed by the United Nations [2].

One innovative way of contributing to achieving the SDGs is to invest in Exchange Traded Funds (ETFs) that track companies that cover these principles. ETFs are novel financial instruments very similar to mutual funds because they are portfolios of assets but with the advantage that they are also easily traded like a stock. Moreover, this article takes into account previous empirical evidence that has extensively employed multi-factor asset pricing models to explain the cross-sectional variation in expected returns of Socially Responsible Investments (SRI). This is the case, for instance, in the recent works of Joliet and Titova [3], who assessed the fundamental characteristics of SRI funds using the Fama-French five-factor model [4], finding that screening criteria guide investment decisions, or Sokolovska and Kešeljević [5] who found both overperformance and underperformance in the 
regional Dow Jones Sustainability Indexes over the period 2006-2016 and stated that renewable energy indices are financially unattractive; however, to the best of our knowledge there is no empirical evidence on SDG assets employing this methodology. Moreover, this article follows the line of Sarwar et al. [6], who proposed estimating this five-factor model using a rolling window and then developing a long-only or a long-short trading strategy where the signals are provided by the model's alpha that represents the risk-adjusted expected return.

It is essential to continue advancing in this line of research in order to connect researchers and investors with the current social challengers. In this sense, previous empirical evidence is improved in SRI in various ways. Firstly, SRI must evolve towards a sustainable investment aligned with the efforts defined by the United Nations (UN) to achieve global sustainable development and concretized in the SDGs due to the fact that investors are called upon to play a relevant role in achieving them. Secondly, it is employed for attractive and innovative financial products such as ETFs that can be traded directly by individual investors in the stock market. This makes SRI more accessible because it brings investors the opportunity of gaining autonomy instead of depend on a professional portfolio manager. Finally, it is provided an active trading strategy based on the use of the traditional methodology that employs multi-factor asset pricing models.

The overall results of this article show the profitability of developing an investment strategy based on the value of the alphas obtained from the estimation of the Fama-French five-factor model [4] when compared to an equally weighted portfolio, even when transaction costs are considered. Additionally, it is shown that investors should focus their investments on two main SDGs: Good health and well-being (Goal 3) and Industry, innovation and infrastructure (Goal 9).

The rest of the paper is organized as follows. In Section 2, a revision of the existing literature about SRI is presented. In Section 3, the methodology employed to construct alternative strategies is described. In Section 4, the database is defined and the descriptive statistics are analyzed. Section 5 details the empirical results of the proposed investment strategies. Section 6 provides the robustness test results. Finally, Section 7 provides the main conclusions.

\section{Literature Review}

Investment with socially responsible criteria has evolved substantially from its beginnings in the late 1960s to the present. Initially, this form of investment was called ethical investment and responded to a diversification practice based on negative screening criteria. More precisely, this type of investment was based on excluding from the investment portfolio "sin" assets, that is, those assets related to tobacco, alcohol, pornography or the gaming industry, among others [7,8]. However, since the 1990s, this type of investment has evolved towards the use of positive screening criteria. This meant considering, within the portfolio selection and management process, good practices of listed companies and investing in companies commonly called "best-in-class" [9-12].

Nevertheless, the concept of SRI did not become popular until the 2000s with the launch of the United Nations Principles for Responsible Investment. In short, the SRI consists of incorporating not only financial aspects such as return, risk and liquidity into the asset selection process, but also other aspects related to the company's good practices in environmental, social or corporate governance matters (ESG). Therefore, the SRI concept is a broad investment idea that encompasses other more specific approaches such as the so-called green investment that only considers the environmental objectives of sustainable investors [13-15] or impact investment that considers social aspects [16].

Despite all this, this article agrees with Betti et al. [17], Cunha et al. [18] and Talan and Sharma [19] in considering that this type of investment must evolve towards a sustainable investment aligned with the important and recent efforts defined by the UN to achieve global sustainable development and be concretized in the SDGs and the 2030 Agenda. In addition, it is important to note that individual and institutional investors are called upon to play an important role in achieving these SDGs.

The literature on SRI has also evolved substantially over time. Initially, the entities managing investment funds played a fundamental intermediation role in stock markets, because they allowed 
and enhanced the transmission of social demands raised by investors, who, in their decision making, desired to value the issuers of securities taking into account ESG aspects in addition to purely financial aspects. Consequently, since the beginning SRI research has focused on analyzing the benefits of socially responsible mutual and pension funds compared to conventional ones. To that end, researchers have employed multi-factor asset pricing models such as the Fama-French three-factor model [20] and the Carhart four-factor model [21] as well as the more recent Fama-French five-factor model [4]. These are of the works of Goldreyer and Diltz [22], Cummings [23], Bello [24], Bauer et al. [25], Gregory and Whittaker [26], Jones et al. [27], Cortez et al. [28], Humphrey and Lee [29], Capelle and Monjon [30], Nofsinger and Varma [31], Lean et al. [32], Leite and Cortez [33], Jin and Han [34] Joliet and Titova [3], Segura et al. [15], Boermans and Galema [35], Martí-Ballester [36] and Martí-Ballester [37], among others.

Meanwhile, it is also necessary to highlight the labor of traditional financial service providers. As a result, SRI indices have been established for different markets and geographic areas to support and promote SRI throughout the world. These indices represent a useful tool for SRI investors, who use them to identify the target companies for their SRI strategies. Because of that, there are also numerous studies that, by employing the same methodology based on multi-factor asset pricing models, have focused on analyzing the evolution and performance of sustainable stock indices compared to conventional ones such as those conducted by Sauer [38], Statman [39], Schröder [40], Consolandi et al. [41] and Managi et al. [42], and more recently by Cunha et al. [18], Jain et al. [43] and Sokolovska and Kešeljević [5].

Both groups of research are very numerous. However, in both cases the results are mixed. Consequently, there is no conclusive answer to the question whether socially responsible funds or indices are more profitable than conventional ones. Despite that, this article considers that the research about SRI should be focused on providing instruments or solutions to the real problems that investors who wish to carry out SRI strategies in the stock markets find themselves with.

In this sense, the recent works of Miralles-Quirós and Miralles-Quirós [44] and Miralles-Quirós et al. [45], which employed ETFs in alternative SRI settings, are highlighted. As was indicated in the introduction section, it is essential to provide investors with innovative financial products that are easily tradable on stock markets. Moreover, this research also follows the works of Kempf and Osthoff [46], Ziegler et al. [47], Brzeszczyński and McIntosh [48] and Berkman and Yang [49], among others, which focused on analyzing portfolios that can be constructed by individual investors themselves on the basis of the ESG data available from listed companies. This is because nowadays individual investors have a greater financial culture, and therefore wish to have their own portfolios adapted to their own ethical and socially responsible criteria. Additionally, these authors create portfolios of assets that go long or short following different criteria and then test the significance of the portfolio returns over different asset pricing models, obtaining dissimilar returns.

Following this objective of developing an active investment strategy, this article adheres to the line of Sarwar et al. [6], who proposed the use of the five-factor model for developing an investment strategy by suggesting different rebalancing periods for the portfolios, which lead to finding profitable strategies when the five-factor model is applied. It is necessary to continue advancing in this line of research in order to contribute to reach the SDGs alternative trading strategies. With that aim, in this research the performance of active trading strategies which take into account the current United Nations challenges is analyzed.

\section{Methodology}

In recent years, different asset pricing models have been developed in order to explain patterns in average returns. Among them, the Sharpe [50] and Lintner [51] Capital Asset Pricing Model (hereinafter CAPM), the Fama-French [20] three-factor model, the Carhart [21] four-factor model and the Fama-French [4] five-factor model have been extensively used to explain the cross-sectional variation in expected returns. 
The seminal works of Sharpe [50] and Lintner [51] proposed the CAPM model, which claims that investors are only compensated for undiversifiable risk. In their model, alpha and beta coefficients are obtained from regressions of stock returns on market returns:

$$
R_{i t}-R_{f t}=\alpha_{i}+\beta_{i}\left(R_{m t}-R_{f t}\right)+\varepsilon_{i t}
$$

where $R_{i t}$ is the asset return for period $t, R_{f}$ is the risk free rate, $R_{m t}$ is the return of the value weighted market index for period $t, \alpha_{i}$ is the Jensen's alpha [52], $\beta_{i}$ is the systematic risk of the asset and $\varepsilon_{i t}$ is the error term.

However, Fama and French [20] showed that there were two well-known patterns in average returns that had been left unexplained by the CAPM model. For that reason, they expanded the CAPM model and add two additional factors which are the size factor SMB (Small Minus Big returns) and the value factor (High Minus Low returns).

$$
R_{i t}-R_{f t}=\alpha_{i}+\beta_{i}\left(R_{m t}-R_{f t}\right)+s_{i} S M B_{t}+h_{i} H M L_{t}+\varepsilon_{i t},
$$

This model was extended by Carhart [21], who included a momentum factor, MOM, which was estimated as the difference between the portfolio returns comprising stocks of winners and losers in the past.

The appearance of some evidence, see Titman et al. [53] and Novy-Marx [54], where it was suggested that the three-factor model fails to capture diverse variations of returns related to profitability and investment, led Fama and French [4] to propose a five-factor model where the differences between the stocks with robust and weak profitability (RMW) and the stocks of low and high investment firms (Conservative Minus Aggressive, CMA) are included:

$$
R_{i t}-R_{f t}=\alpha_{i}+\beta_{i}\left(R_{m t}-R_{f t}\right)+s_{i} S M B_{t}+h_{i} H M L_{t}+r_{i} R M W_{t}+c_{i} C M A_{t}+\varepsilon_{i t},
$$

Fama and French [4] pointed out that the main strength of this model is that it provides an overall better description of average returns than the three-factor model, which is likely to fare poorly when applied to portfolios with strong profitability and investment tilts.

There is extensive empirical evidence that analyzes these models on different datasets, Fama and French [55], Foye [56] and Mohanty [57] being some of the most recent. Fama and French [55] tested both the three- and the five-factor models on a set of 23 developed markets. They found evidence that the model performs better in North America and Europe and for big stocks. They also found that both three- and five-factor models perform poorly in tests on regional portfolios, therefore, they suggested concentrating on local models. Moreover, Foye [56] tested the performance of the five-factor model across 18 countries from three different regions. He found that the five-factor model outperformed the three-factor one in Eastern Europe and Latin America but failed in the Asian region. From an SRI perspective, the works of Joliet and Titova [3] and Sokolovska and Kešeljević [5] also employed this five factor model in order to analyses the performance of different SRI funds an indices, respectively. On the other hand, Mohanty [57] tested different asset models on 22 developed markets and 21 emerging markets and pointed out that each market is unique in its composition and trend, and hence, a generalized approach cannot be adopted across all the markets.

Beside the empirical evidence, which is only focused on analyzing the performance of a dataset on a fixed sample, there are some authors who acknowledged the time-varying nature of the coefficients of the models. Bauer et al. [58] performed rolling regressions to test for the stability of some of the asset pricing models, finding evidence that ethical funds do not outperform relative to conventional funds. Mateus et al. [59] followed the approach proposed by Angelidis et al. [60] for analyzing the performance of a huge set of UK mutual funds. They revealed that both the Fama-French three-factor and the Carhart four-factor models amplified the underperformance of UK equity mutual funds. Hoewver, as previously indicated, there are other lines of research, such as those of Kempf and Osthoff [46], 
Ziegler et al. [47], Brzeszczyński and McIntosh [48] and Berkman and Yang [49], that created a portfolio of assets that go long or short following different criteria and then test the significance of the portfolio returns over different asset pricing models obtaining dissimilar returns.

Moreover, expected stock returns have been time-varying estimated or modelled using different asset pricing models by a broad range of articles such as Campbell and Shiller [61], Fama and French [62], Fama and French [63], Herold and Maurer [64] or Basiewicz and Auret [65]. There have also been studies where the expected values were used to guide sector rotation strategies by taking long or short positions on portfolios on the basis of the returns, see Beller et al. [66] or Chong and Philips [67], among others.

However, the methodology employed in this article is not based on the expected returns but on the alphas of these models and, more precisely, on the alphas of the Fama-French five-factor model due to its best performance when compared to the rest of the asset pricing models. This alpha, which is also known as the Jensen's alpha, is the constant (intercept) in these asset pricing models and "risk adjusts" the excess returns for the different factors in the models. It is considered that a statistically significant positive (negative) alpha indicates a superior (inferior) performance of the asset in relation to the market.

In this article, the line of the approach proposed by Sarwar et al. [6] is followed, of estimating the Fama-French five-factor model using a rolling window and then developing a long-only, a long-only with risk free asset and a long-short strategy where the signals are provided by the Jensen's alpha. Therefore, a buy (sell or investing on risk free asset) signal appears for an asset on period $t+1$ when the alpha for the rolling window ending on period $t$ is positive (negative).

However, this article proposes some methodological differences with respect to the Sarwar et al. [6] approach. Firstly, they used monthly data, but we opted for using daily data due to the empirical evidence, see Morse [68], Brown and Warner [69] and Campbell et al. [70], among others. Secondly, we rebalanced the position every day and evaluated the performance of the proposed strategies by comparing their results on the Sharpe and Sortino ratios with those obtained from an equally weighted portfolio (naïve) strategy.

The Sharpe ratio can be defined as the sample mean of excess returns on the risk-free asset, divided by their sample standard deviation. Following Bessler and Wolff [71], as the risk-free rate we used the yield of a three-month US Treasury Bill:

$$
\text { Sharpe }=\frac{\hat{\mu}-r_{f}}{\hat{\sigma}},
$$

The Sortino ratio (see Sortino and Satchell [72] and Sortino [73]) is very similar to the former, but instead of dividing the excess return by the sample standard deviation, it is divided by the downside deviation, which only considers excess returns below zero:

$$
\text { Sortino }=\frac{\hat{\mu}-r_{f}}{\text { Downside deviation }},
$$

The naïve portfolio was used as a benchmark, because, as pointed out by DeMiguel et al. [74], this strategy is easy to implement because it does not rely on either estimation of the moments of asset returns or on optimization, and because investors continue to use such simple allocation rules for allocating their assets.

Thirdly, instead of investing in risk free assets only in recession periods as Sarwar et al. [6] did, we opted for investing in these assets when the alpha was negative for the whole out-of-sample period. The main reason for this different procedure is the fact that there were no significant recession periods in the sample we chose in accordance with the US Business Cycle Expansions and Contractions reported by the Federal Reserve Bank of St. Louis.

Finally, a rolling window alpha of the previous 60 months (5-years) was employed instead of the 36-months rolling window used by Sarwar et al. [6]. This fact led to 1256 observations for alphas 
and returns for each strategy. This article followed the common procedure for assessing time-varying alphas and/or betas of Fama and MacBeth [75], Griffin [76], Mishra et al. [77], Barth et al. [78], Verheyden et al. [79] and Zeng [80], among others. Additionally, Morningstar, which is a leading provider of investment analysis in the mutual fund industry, used a default period of 60 months for estimating most of its performance measures.

\section{Database}

Daily returns from 1 October 2008 to 28 September 2018 (amounting to 2517 usable observations) of 15 ETFs that invest in companies that help achieve the UN SDGs were employed. For each selected goal we have chosen the ETF with longer inception dates and those with higher assets under management, the market value of total assets that a fund has accumulated and now manages on behalf of investors. All the ETFs are traded in the Nasdaq, which was also the provider of the historical data (see http://www.nasdaq.com).

As is reported in Table 1, the selected SDG ETFs were as follows: the Health Care Selected Sector SPDR Fund (XLV) and the Vanguard Health Care ETF (VHT), which are related to Good health and well-being (Goal 3); the PowerShares Water Resources Portfolio (PHO), the Invesco S\&P Global Water Index ETF (CGW), the First Trust Water ETF (FIW) and the Invesco Global Water ETF (PIO), which are related to Clean water and sanitation (Goal 6); the Invesco Solar ETF (TAN, the iShares Global Clean Energy ETF (ICLN), the Invesco WilderHill Clean Energy ETF (PBW) and the VanEck Vectors Global Alternative Energy ETF (GEX) linked with Affordable and clean energy (Goal 7); the iShares Russell 100 Growth ETF (IWF) and the Vanguard Growth ETF (VUG) connected to Decent work and economic growth (Goal 8); the Technology Selected Sector SPDR Fund (XLK), the iShares NASDAQ Biotechnology ETF (IBB) and the Invesco Cleantech ETF (PZD), which are associated with Industry, innovation and infrastructure (Goal 9); the VanEck Vectors Environmental Services ETF (EVX), which is linked to Sustainable cities and communities (Goal 11); finally, the iShares MSCI KLD 400 Social ETF (DSI) and the iShares MSCI USA ESG Select ETF (SUSA), which are connected to Responsible consumption and production (Goal 12). All of them are ETFs that invest in the equity of companies which cover principles such as company ethics, environmentally friendliness and human rights and that consider financial returns as well as social good according to the United Nations' Social Development Goals.

There are two main reasons for employing ETFs. Firstly, ETFs are a portfolio of assets, like mutual funds, but they are also easily traded like a stock. Moreover, ETFs have advantages in terms of intraday liquidity, transparency and fiscal efficiency that mutual funds do not have. Secondly, there are a wide variety of ETFs actively traded on the US stock market that allow investors to reward companies that invest responsibly to help achieve the UN SDGs. Goals 3, 6, 7, 8, 9, 11 and 12 are chosen because they are the most investable into the goals that can be named as planet and prosperity, which are those that require an urgent action from investors and corporations. The role of corporations must be considered because they have the potential of making a significant contribution to developing, for example, Goals 7,9 and 12 .

Table 2 reports the main descriptive statistics and stochastic properties of the ETF's returns. On average, ETFs related to Goals 3, 8 and 9 realized higher returns and lower volatilities than the rest over the sample period. On the other hand, those ETFs linked to Goals 6 and 7 appeared to be more volatile and provided lower mean returns (even negative ones for those ETFs connected to Goal 7). On the basis of the ANOVA test, we rejected the null hypothesis that all the return series have the same mean because those differences are statistically significant. 
Table 1. Exchange Traded Funds and Sustainable Development Goals.

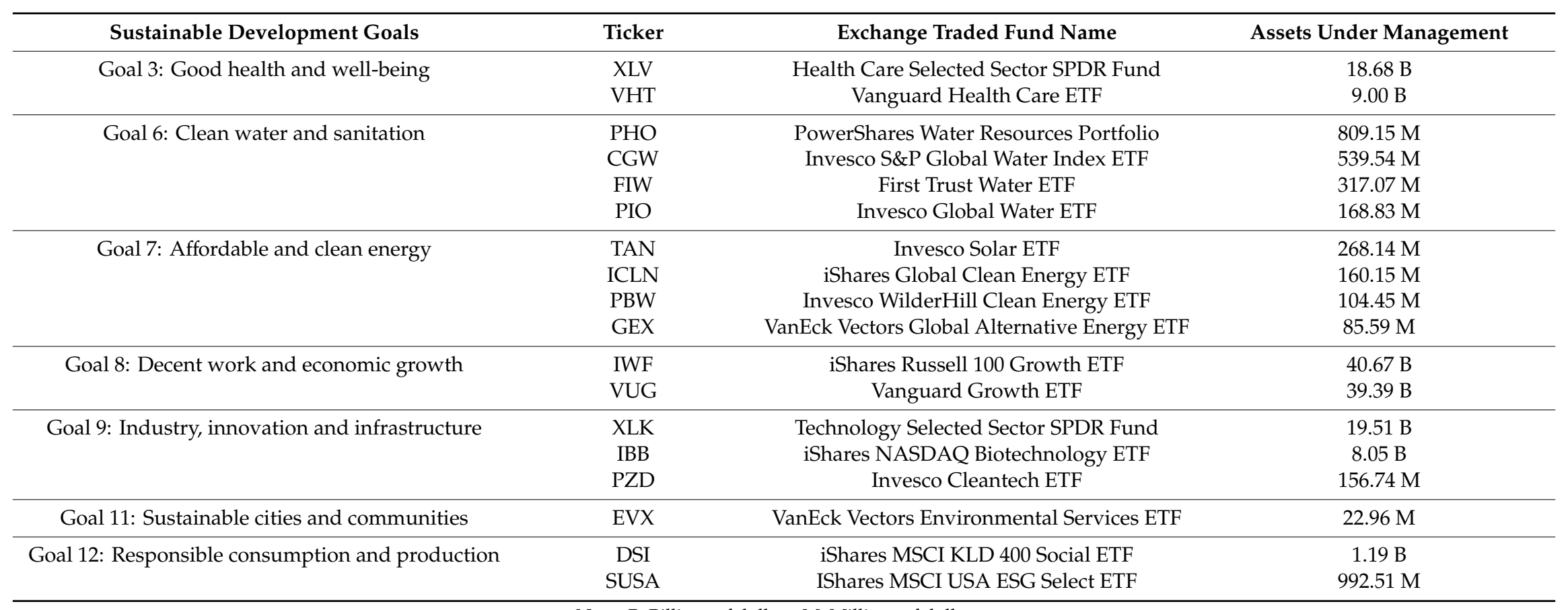

Note: B: Billions of dollars; M: Millions of dollars. 
Table 2. Descriptive Statistics.

\begin{tabular}{|c|c|c|c|c|c|c|}
\hline Sustainable Development Goals & Ticker & Mean & Standard Deviation. & Skewness & Kurtosis & Jarque-Bera \\
\hline \multirow[t]{2}{*}{ Goal 3: Good health and well-being } & XLV & 0.0004 & 0.0108 & -0.306 & 14.653 & $14,276.15$ \\
\hline & VHT & 0.0004 & 0.0111 & -0.231 & 11.808 & 8157.19 \\
\hline \multirow[t]{4}{*}{ Goal 6: Clean water and sanitation } & $\mathrm{PHO}$ & 0.0002 & 0.0157 & -0.319 & 12.595 & 9695.46 \\
\hline & CGW & 0.0002 & 0.0138 & -0.476 & 16.886 & $20,309.18$ \\
\hline & FIW & 0.0003 & 0.0147 & -0.643 & 11.635 & 7990.87 \\
\hline & $\mathrm{PIO}$ & 0.0001 & 0.0145 & -0.089 & 18.457 & $25,051.99$ \\
\hline \multirow[t]{4}{*}{ Goal 7: Affordable and clean energy } & TAN & -0.0008 & 0.029 & -0.234 & 9.727 & 4767.88 \\
\hline & ICLN & -0.0005 & 0.0215 & -0.539 & 15.006 & $15,234.2$ \\
\hline & PBW & -0.0004 & 0.0211 & -0.425 & 9.552 & 4577.46 \\
\hline & GEX & -0.0002 & 0.021 & -0.529 & 15.752 & $17,166.68$ \\
\hline \multirow[t]{2}{*}{ Goal 8: Decent work and economic growth } & IWF & 0.0004 & 0.0118 & -0.197 & 14.132 & $13,008.91$ \\
\hline & VUG & 0.0004 & 0.012 & -0.261 & 14.479 & $13,842.91$ \\
\hline \multirow[t]{3}{*}{ Goal 9: Industry, innovation and infrastructure } & XLK & 0.0005 & 0.0127 & 0.172 & 13.3 & $11,134.96$ \\
\hline & IBB & 0.0006 & 0.0155 & -0.222 & 5.556 & 705.99 \\
\hline & PZD & 0.0001 & 0.0164 & -0.694 & 15.442 & $16,433.35$ \\
\hline Goal 11: Sustainable cities and communities & EVX & 0.0003 & 0.0136 & -0.406 & 11.333 & 7349.65 \\
\hline \multirow[t]{2}{*}{ Goal 12: Responsible consumption and production } & DSI & 0.0003 & 0.0117 & -0.556 & 13.674 & $12,076.02$ \\
\hline & SUSA & 0.0003 & 0.0116 & -0.474 & 12.395 & 9349.3 \\
\hline
\end{tabular}

This table contains the descriptive statistics for the daily return series for the Sustainable Development Goals ETFs for the sample period from October 1, 2008 through September 28, 2018.

The last column reports the mean and variance equality tests using the ANOVA and Levene statistics, respectively. Skewness and Kurtosis refer to the series skewness and kurtosis

coefficients. The Jarque-Bera statistic tests the normality of the series. This statistic has an asymptotic $\chi^{2}(2)$ distribution under the normal distribution hypothesis. 
Additionally, the rejection of the null of equality of variances led us to conclude that differences are statistically significant. Skewness was always negative and kurtosis was higher than 3 in all cases, therefore, the distributions of returns for all the ETFs were negatively skewed and leptokurtic. Finally, the Jarque-Bera statistic rejected the null hypothesis that the returns are normally distributed in all cases.

\section{Empirical Results}

At this stage, once the rolling Fama-French five-factor regressions for each ETF are estimated using the Eviews software, we show in Table 3 the performance of four strategies: the naïve or equally weighted portfolio strategy where the sign of the model intercept (alpha) do not matter, the long-only strategy, the long-short strategy and the long-risk free strategy. In the last three, the signals are provided by Jensen's alpha; therefore, a long (short or risk-free investment) signal appears for an asset on period $t+1$ when the alpha for the rolling window ending on period $t$ is positive (negative). All these strategies and performance measures were calculated using a spreadsheet.

It is observed that the long-only strategy clearly outperforms the naïve strategy. Its annualized mean return $(12.89 \%)$ is almost twice that obtained by following a strategy of investing the same weight on each asset (6.99\%). This return leads to better performance ratios, 0.6937 vs. 0.4780 when the Sharpe ratio is considered and 0.9984 vs. 0.6544 when the Sortino ratio is chosen, even when the annualized standard deviation is bigger for the long-only strategy. Finally, it must be pointed out that an investor who opts for investing only on those ETFs with positive alphas would obtain a $64.28 \%$ cumulated return, which is clearly better than the $34.89 \%$ cumulated return that would be obtained following a naïve strategy where no regressions or estimates are considered. This better performance is clearly shown in Figure 1 where the evolution of each cumulated return is displayed.

Table 3. Performance from alpha's strategies.

\begin{tabular}{cccccc}
\hline Trading Strategy & Mean (\%) & SD (\%) & Sharpe & Sortino & CR (\%) \\
\hline Naïve & 6.99 & 13.69 & 0.4780 & 0.6544 & 34.89 \\
Long only & 12.89 & 17.93 & 0.6937 & 0.9984 & 64.28 \\
Long-Short & -3.59 & 10.10 & -0.4000 & -0.5867 & -17.89 \\
Long-Risk free & 2.09 & 2.77 & 0.5914 & 0.8410 & 10.42 \\
\hline
\end{tabular}

This table shows portfolio performance after applying the different strategies. The values of mean returns, standard deviations (SD) and cumulative returns (CR) are annualized and reported as percentages. The Naïve row shows the results obtained from an equally weighted portfolio. Strategies take a long (short or invest in 1-month US T-Bill) position in the portfolio that have positive (negative) alpha of 5-year rolling window regression.

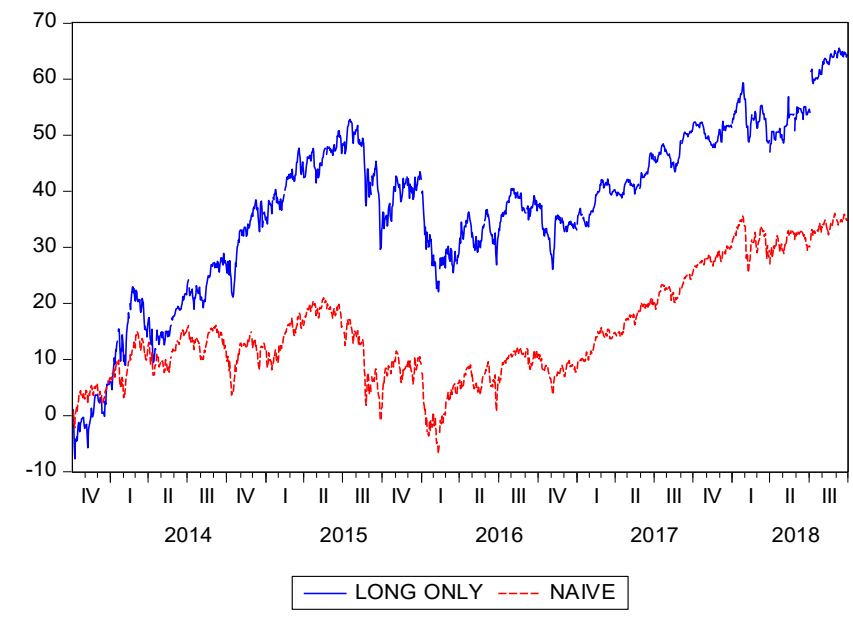

Figure 1. Cumulative Returns for Long only and Naïve strategies. 
The rest of the strategies provide dissimilar results when compared with the naïve strategy. Therefore, the long-risk free strategy improves the naïve one in terms of standard deviation and Sharpe and Sortino ratios; however, the long-short strategy clearly underperforms the naïve strategy because it provides negative amounts for all the performance values. This result agrees with those obtained by Sarwar et al. [6], where the worst results were provided by that strategy.

Table 4 reports the number and percentage of positive and negative alphas over the out-of-sample period. From these results we observe that the profitable long-only strategy is mainly compounded by three ETFs: XLV and VHT, which are related to Goal 3 (Good health and well-being), and the IBB connected to Goal 9 (Industry, innovation and infrastructure) and to a lesser extent by the EVX ETF (Goal 11: Sustainable cities and communities) and XLK (Goal 9).

Table 4. Positive and negative alphas over the rolling window.

\begin{tabular}{cccccc}
\hline Sustainable Development Goals & ETF & POS & $\%$ & NEG & $\%$ \\
\hline Goal 3: Good health and well-being & XLV & 1008 & 80.25 & 248 & 19.75 \\
& VHT & 1055 & 84.00 & 201 & 16.00 \\
\hline Goal 6: Clean water and sanitation & PHO & 0 & 0.00 & 1256 & 100.00 \\
& CGW & 0 & 0.00 & 1256 & 100.00 \\
& FIW & 0 & 0.00 & 1256 & 100.00 \\
& PIO & 0 & 0.00 & 1256 & 100.00 \\
\hline Goal 7: Affordable and clean energy & TAN & 0 & 0.00 & 1256 & 100.00 \\
& ICLN & 0 & 0.00 & 1256 & 100.00 \\
& PBW & 0 & 0.00 & 1256 & 100.00 \\
Goal 8: Decent work and economic growth & GEX & 0 & 0.00 & 1256 & 100.00 \\
\hline Goal 9: Industry, innovation and infrastructure & IWF & 0 & 0.00 & 1256 & 100.00 \\
& VUG & 0 & 0.00 & 1256 & 100.00 \\
\hline GLK & 51 & 4.06 & 1205 & 95.94 \\
& IBB & 1052 & 83.76 & 204 & 16.24 \\
\hline Goal 12: Responsible consumption and production & PZD & 0 & 0.00 & 1256 & 100.00 \\
\hline
\end{tabular}

This table reports the number of positive (POS) and negative (NEG) alphas and the percentage over the total of rolling five-factor model regressions (1256) for each Exchange Traded Fund (ETF).

The fact that positive alphas and, therefore, the existence of an investment opportunity being focused on sectors linked to Healthcare (XLV and VHT) and Biotechnology (IBB), which is strongly connected to Healthcare, agree with the conclusions reached by Betti et al. [17] who stated that Healthcare is the single most important sector for achieving the SDGs. That statement is reinforced by these results and, therefore, should be taken into account by investors in order to build their portfolios. In contrast, the negative values for the rest of the SDG references lead us to consider that they provide an inferior performance in relation to the market, and consequently they are not suitable to be considered for investment by investors, because a short position combined with the long one provides negative performances as is shown in Table 3.

\section{Robustness Test}

In order to provide more robustness to the results, we compared them with those obtained from two other approaches. The first procedure is similar to that proposed by [6]. In this case we used monthly data to estimate the Jensen's alphas but used a 60-month rolling window instead of the 36-month rolling window employed by them. Once the alphas had been estimated, we used daily data to estimate the returns and performance of the portfolio, but the weights of each asset were rebalanced monthly. Therefore, a long (short or risk-free investment) signal appears for an asset on month $t+1$ when the alpha for the rolling window ending on month $t$ is positive (negative). 
A second procedure was also proposed where portfolios are rebalanced monthly as with the previous alternative but alphas are estimated using daily data and a 60-month rolling window. From the results reported in Table 5 we can observe that there is no reason for rebalancing the portfolio weights monthly because both alternative approaches clearly underperform the initial procedure.

Besides the annualized mean return of $12.89 \%$ that is obtained using daily data and rebalancing daily, there is a drop to a $10.84 \%$ mean return when monthly data and rebalancing is used as the authors in [6] proposed. There is an improvement when daily data is employed for estimating the alphas in spite of the portfolio being rebalanced monthly, the mean return rises to $11.51 \%$, but this is not enough to outperform the initial proposal. The Sharpe and Sortino ratios are also worse (not higher than 0.6165 and 0.8787 , respectively, when the previous ones were 0.6937 and 0.9984 , respectively), and finally, the cumulative return is not higher than $57.35 \%$ which is significantly lower than the $64.28 \%$ obtained using the initial approach.

Table 5. Performance from alpha's strategies and alternatives.

\begin{tabular}{cccccc}
\hline \multicolumn{5}{c}{ 5-year rolling window } \\
\hline Trading Strategy & Mean (\%) & SD (\%) & Sharpe & Sortino & CR (\%) \\
\hline Naïve & 6.99 & 13.69 & 0.4780 & 0.6544 & 34.89 \\
Long only & 12.89 & 17.93 & 0.6937 & 0.9984 & 64.28 \\
Long-Short & -3.59 & 10.10 & -0.4000 & -0.5867 & -17.89 \\
Long-Risk free & 2.09 & 2.77 & 0.5914 & 0.8410 & 10.42 \\
\hline \multicolumn{5}{c}{ Sawar (2018) } \\
\hline Trading Strategy & Mean (\%) & SD (\%) & Sharpe & Sortino & CR (\%) \\
\hline Naïve & 6.99 & 13.69 & 0.4780 & 0.6544 & 34.89 \\
Long only & 10.84 & 17.06 & 0.6091 & 0.8516 & 54.05 \\
Long-Short & -3.94 & 10.07 & -0.4359 & -0.6380 & -19.63 \\
Long-Risk free & 1.94 & 2.73 & 0.35451 & 0.7661 & 9.68 \\
\hline & Alternative & & \\
\hline Trading Strategy & Mean (\%) & SD (\%) & Sharpe & Sortino & CR (\%) \\
\hline Naïve & 6.99 & 13.69 & 0.4780 & 0.6544 & 34.89 \\
Long only & 11.51 & 17.93 & 0.6165 & 0.8787 & 57.35 \\
Long-Short & -3.77 & 10.07 & -0.4193 & -0.6149 & -18.79 \\
Long-Risk free & 2.00 & 2.77 & 0.5591 & 0.7929 & 9.97 \\
\hline
\end{tabular}

This table shows portfolio performance after applying the different strategies. The values of mean returns, standard deviations (SD) and cumulative returns (CR) are annualized and reported as percentages. The Naïve row shows the results obtained from an equally weighted portfolio. Strategies take a long (short or invest in 1-month US T-Bill) position in the portfolio that have a positive (negative) alpha of 5-year rolling window regression.

In order to reinforce the better performance of the initial proposal we show, in Figure 2, the cumulative returns of the long-only strategies of the original (denoted as Long-only) and the other two methodologies proposed for testing its robustness, where we observe that the initial approach clearly outperforms the others. 


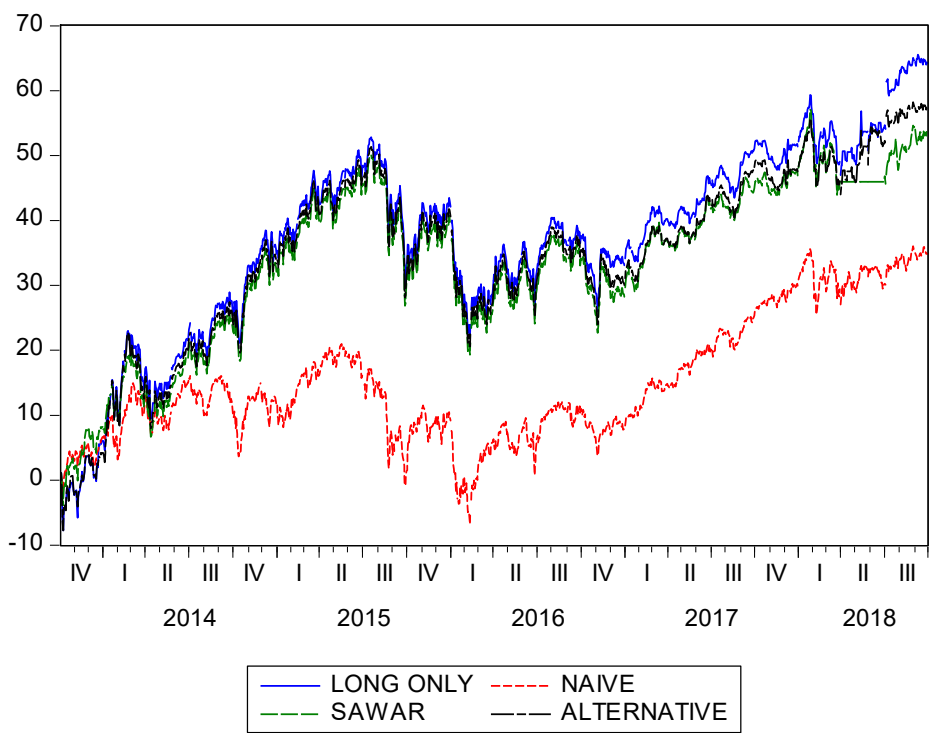

Figure 2. Cumulative Returns for each strategy.

Finally, the expense ratios incurred by ETF managers must be taken into account, because, as pointed out by Blitz and Huij [81], the average active fund underperforms the market portfolio by the magnitude of its expenses. In Table 6, we show the results of out-of-sample portfolio performance considering a $0.56 \%$ annual expense ratio (which corresponds with the mean of the expense ratios from the ETFs considered in this paper). It is observed that the profitability of the proposal sufficiently takes into account the expense ratios and, moreover, is better than the alternatives.

Table 6. Performance from alpha's strategies and alternatives (considering transaction costs).

\begin{tabular}{cccccc}
\hline \multicolumn{5}{c}{ 5-year rolling window } \\
\hline Trading Strategy & Mean (\%) & SD (\%) & Sharpe & Sortino & CR (\%) \\
\hline Naïve & -0.05 & 13.69 & -0.0371 & -0.0498 & -0.28 \\
Long only & 11.75 & 17.94 & 0.6301 & 0.9046 & 58.60 \\
Long-Short & -10.64 & 10.10 & -1.0981 & -1.5539 & -53.06 \\
Long-Risk free & 0.95 & 2.77 & 0.1802 & 0.2516 & 4.74 \\
\hline \multicolumn{7}{c}{ Sawar (2018) } & & & \\
\hline Trading Strategy & Mean (\%) & SD (\%) & Sharpe & Sortino & CR (\%) \\
\hline Naïve & -0.05 & 13.69 & -0.0371 & -0.0498 & -0.28 \\
Long only & 9.82 & 17.05 & 0.5494 & 0.7661 & 48.97 \\
Long-Short & -10.99 & 10.07 & -1.1365 & -1.6043 & -54.79 \\
Long-Risk free & 0.92 & 2.73 & 0.1725 & 0.2384 & 4.60 \\
\hline Alternative & & & \\
\hline Trading Strategy & Mean (\%) & SD (\%) & Sharpe & Sortino & CR (\%) \\
\hline Naïve & -0.05 & 13.69 & -0.0371 & -0.0498 & -0.28 \\
Long only & 10.36 & 17.92 & 0.5527 & 0.7857 & 51.64 \\
Long-Short & -10.82 & 10.07 & -1.1199 & -1.5843 & -53.95 \\
Long-Risk free & 0.85 & 2.76 & 0.1459 & 0.2032 & 4.27 \\
\hline
\end{tabular}

This table shows portfolio performance after applying the different strategies. The values of mean returns, standard deviations (SD) and cumulative returns (CR) are annualized and reported as percentages. The Naïve row shows the results obtained from an equally weighted portfolio. Strategies take a long (short or invest in 1-month US T-Bill) position in the portfolio that have positive (negative) alpha of 5-year rolling window regression. 


\section{Conclusions}

The UN's SDGs published in 2015 are a set of 17 ambitious targets for making the world a better place. These SDGs offer a path to value creation not only for society but also for investors. In view of this, the objective of this article has been to enhance the evidence on the benefits for investors of combining their target of getting positive financial returns and contributing to a sustainable development agenda by considering the UN's SDGs.

Instead of following the previous empirical evidence, which is focused on testing the performance of the asset pricing models, this article opted for developing different investment strategies based on the value of the alphas obtained from the estimation of the Fama-French five-factor model. Therefore, four strategies were developed: the naïve or equally weighted portfolio strategy, where the sign of the model intercept (alpha) did not matter, but also the long-only strategy, the long-short strategy and the long-risk free strategy, where the signals are provided by the Jensen's alpha.

It was observed that the long-only strategy, which is mainly compounded by ETFs connected to Goals 3 (Good health and well-being) and 9 (Industry, innovation and infrastructure), clearly outperformed the naïve strategy but also the other two strategies, which provide dissimilar results when compared with the naïve strategy because the long-risk free strategy improved it but the long-short one clearly underperformed it.

In order to test the robustness of the results, other approaches were considered, in addition to the transaction costs. It was shown that these alternative approaches did not improve the methodology proposed and that it is possible to outperform the performance of an equally weighted portfolio even when transaction costs are considered.

From the results of this work, it is reflected that investors should mainly focus on assets that are linked to two main goals: Good health and well-being (Goal 3) and Industry, innovation and infrastructure (Goal 9). In other words, it is shown that the Healthcare sector is now the most important for investors who want to obtain some profits from their investments, but the Biotechnology sector, which is closely related to the Healthcare one, should also be considered. These results are applicable to individual and institutional investors who can use these techniques to add social and economic value to their investment strategies.

Author Contributions: This work is an outcome of the joint efforts of the three authors. J.L.M.-Q. conceived the research idea, provided research materials and analysis tools and contributed to the interpretation of the results. M.M.M.-Q. conceived the research idea and reviewed the related literature. J.M.N. contributed to the research idea, compiled the data and analyzed the results. All authors provided contributions to the conclusion and implications of the research. All authors have read and agreed to the published version of the manuscript.

Funding: This research was funded by Junta de Extremadura under the VI Action Plan for Research and Development 2017/20 through the GIMAF research group (reference GR18022).

Conflicts of Interest: The authors declare no conflict of interest.

\section{References}

1. United Nations. Transforming our World: The 2030 Agenda for Sustainable Development. Resolution A/70/L.1. 25 September 2015. Available online: https://www.un.org/en/development/desa/population/migration/ generalassembly/docs/globalcompact/A_RES_70_1_E.pdf (accessed on 24 February 2020).

2. United Nations. The SDG Investment Case. An Investor Initiative in Partnership with UNEP Finance Initiative, UN Global Compact and Price Water Hose Coopers. 12 October 2017. Available online: https://www.unpri. org/sdgs/investors-and-the-sustainable-development-goals/304.article (accessed on 24 February 2020).

3. Joliet, R.; Titova, Y. Equity SRI funds vacillate between ethics and money: An analysis of the funds' stock holding decisions. J. Bank. Financ. 2018, 97, 70-86. [CrossRef]

4. Fama, E.F.; French, K.R. A five-factor asset pricing model. J. Financ. Econ. 2015, 116, 1-22. [CrossRef]

5. Sokolovska, I.; Kešeljević, A. Does sustainability pay off? A multi-factor analysis on regional DJSI and renewable stock indices. Economic Research- Ekon. Istraživanja 2019, 32, 423-439. [CrossRef] 
6. Sarwar, G.; Mateus, C.; Todorovic, N. US sector rotation with five-factor Fama-French alphas. J. Asset Manag. 2018, 19, 116-132. [CrossRef]

7. Renneboog, L.; Ter Horst, J.; Zhang, C. Socially responsible investments: Institutional aspects, performance, and investor behaviour. J. Bank. Financ. 2008, 32, 1723-1742. [CrossRef]

8. Sandberg, J.; Juravle, C.; Hedesström, T.M.; Hamilton, I. The Heterogeneity of Socially Responsible Investment. J. Bus. Ethics 2009, 87, 519-533. [CrossRef]

9. Eccles, N.S.; Viviers, S. The Origins and Meanings of Names Describing Investment Practices that Integrate a Consideration of ESG Issues in the Academic Literature. J. Bus. Ethics 2011, 104, 389-402. [CrossRef]

10. Goettsche, M.; Steindl, T.; Gietl, S. Do customers affect the value relevance of sustainability reporting? Empirical evidence on stakeholder interdependence. Bus. Strategy Environ. 2016, 25, 149-164. [CrossRef]

11. McWilliams, A.; Parhankangas, A.; Coupet, J.; Welch, E. Strategic decision making for the triple bottom line. Bus. Strategy Environ. 2016, 25, 193-204. [CrossRef]

12. Miralles-Quirós, M.M.; Miralles-Quiros, J.L.; Arraiano, I.G. Sustainable Development, Sustainability Leadership and Firm Valuation: Differences across Europe. Bus. Strategy Environ. 2017, 26, 1014-1028. [CrossRef]

13. Silva, F.; Cortez, M.C. The performance of US and European green funds in different market conditions. J. Clean. Prod. 2016, 135, 558-566. [CrossRef]

14. Allevi, E.; Basso, A.; Bonenti, G.; Oggioni, G.; Riccardi, O. Measuring the environmental performance of green SRI funds: A DEA approach. Energy Econ. 2019, 79, 32-44. [CrossRef]

15. Segura, S.; Ferruz, L.; Salvador, M. Environmental versus economic performance in the EU ETS from the point of view of policy makers: A statistical analysis based on copulas. J. Clean. Prod. 2018, 176, 1111-1132. [CrossRef]

16. Höchstädter, A.K.; Scheck, B. What's in a Name: An Analysis of Impact Investing Understandings by Academics and Practitioners. J. Bus. Ethics 2015, 132, 449-475. [CrossRef]

17. Betti, G.; Consolandi, C.; Eccles, R.G. The relationship between investor materiality and the sustainable development goals: A methodological framework. Sustainability 2018, 10, 2248. [CrossRef]

18. Cunha, F.A.F.S.; Oliveira, E.M.; Orsato, R.J.; Klotzle, M.C.; Oliveira, F.L.C.; Caiado, R.G.G. Can sustainable investments outperform traditional benchmarks? Evidence from global stock markets. Bus. Strategy Environ. 2019. [CrossRef]

19. Talan, G.; Sharma, G. Doing well by doing good: A systematic review and research agenda for sustainable investment. Sustainability 2019, 11, 353. [CrossRef]

20. Fama, E.F.; French, K.R. Common risk factors in the returns on stocks and bonds. J. Financ. Econ. 1993, 33, 3-56. [CrossRef]

21. Carhart, M. On persistence in mutual fund performance. J. Financ. 1997, 52, 57-82. [CrossRef]

22. Goldreyer, E.; Diltz, J. The performance of socially responsible mutual funds: Incorporating sociopolitical information in portfolio selection. Manag. Financ. 1999, 25, 23-36. [CrossRef]

23. Cummings, L. The financial performance of ethical investment trusts: An Australian perspective. J. Bus. Ethics 2000, 25, 79-92. [CrossRef]

24. Bello, Z. Socially responsible investing and portfolio diversification. J. Financ. Res. 2005, 28, 41-57. [CrossRef]

25. Bauer, R.; Derwall, J.; Otten, R. The ethical mutual fund performance debate: New evidence from Canada. J. Bus. Ethics 2007, 70, 111-124. [CrossRef]

26. Gregory, A.; Whittaker, J. Performance and performance persistence of ethical unit trusts in the UK. J. Bus. Financ. Account. 2007, 34, 1327-1344. [CrossRef]

27. Jones, S.; Van der Laan, S.; Frost, S.; Loftus, J. The investment performance of socially responsible investment funds in Australia. J. Bus. Ethics 2008, 80, 181-203. [CrossRef]

28. Cortez, M.C.; Silva, F.; Areal, N. The performance of European socially responsible funds. J. Bus. Ethics 2009, 87, 573-588. [CrossRef]

29. Humphrey, J.E.; Lee, D.D. Australian socially responsible funds: Performance, risk and screening intensity. J. Bus. Ethics 2011, 102, 519-535. [CrossRef]

30. Capelle, G.; Monjon, S. The performance of socially responsible funds: Does the screening process matter? Eur. Financ. Manag. 2014, 20, 494-520. [CrossRef]

31. Nofsinger, J.; Varma, A. Socially responsible funds and market crises. J. Bank. Financ. 2014, 48, 180-193. [CrossRef] 
32. Lean, H.H.; Ang, W.R.; Smyth, R. Performance and performance persistence of socially responsible investment funds in Europe and North America. N. Am. J. Econ. Financ. 2015, 34, 254-266. [CrossRef]

33. Leite, P.; Cortez, M.C. Performance of European socially responsible funds during market crises: Evidence from France. Int. Rev. Financ. Anal. 2015, 40, 132-141. [CrossRef]

34. Jin, J.; Han, L. Assessment of Chinese green funds: Performance and industry allocation. J. Clean. Prod. 2018, 171, 1084-1093. [CrossRef]

35. Boermans, M.A.; Galema, R. Are pension funds actively decarbonizing their portfolios? Ecol. Econ. 2019, 161, 50-60. [CrossRef]

36. Martí-Ballester, C.P. The role of mutual funds in the sustainable energy sector. Bus. Strategy Environ. 2019, 28, 1107-1120. [CrossRef]

37. Martí-Ballester, C.P. Examining the financial performance of pension funds focused on sectors related to sustainable development goals. Int. J. Sustain. Dev. World Ecol. 2020. [CrossRef]

38. Sauer, D. The impact of social-responsibility screens on investment performance: Evidence from the Domini 400 social index and Domini equity fund. Rev. Financ. Econ. 1997, 6, 23-35. [CrossRef]

39. Statman, M. Socially responsible mutual funds. Financ. Anal. J. 2000, 56, 30-39. [CrossRef]

40. Schröder, M. Is there a difference? The performance characteristics of SRI equity indices. J. Bus. Financ. Account. 2007, 34, 331-348. [CrossRef]

41. Consolandi, C.; Jaiswal-Dale, A.; Poggiani, E.; Vercelli, A. Global standards and ethical stock indexes: The case of the Dow Jones sustainability Stoxx index. J. Bus. Ethics 2009, 87, 185-197. [CrossRef]

42. Managi, S.; Okimoto, T.; Matsuda, A. Do socially responsible investment indexes outperform conventional indexes? Appl. Financ. Econ. 2012, 22, 1511-1527. [CrossRef]

43. Jain, M.; Sharma, G.D.; Srivastava, M. Can sustainable investment yield better financial returns: A comparative study of ESG índices and MSCI índices. Risks 2019, 7, 15. [CrossRef]

44. Miralles-Quirós, J.L.; Miralles-Quirós, M.M. Are alternative energies a real alternative for investors? Energy Econ. 2019, 78, 535-545. [CrossRef]

45. Miralles-Quirós, J.L.; Miralles-Quirós, M.M.; Nogueira, J.M. Diversification benefits of using exchange-traded funds in compliance to the sustainable development goals. Bus. Strategy Environ. 2019, 28, 244-255. [CrossRef]

46. Kempf, A.; Osthoff, P. The effect of socially responsible investing on portfolio performance. Eur. Financ. Manag. 2007, 13, 908-922. [CrossRef]

47. Ziegler, A.; Busch, T.; Hoffmann, V.H. Disclosed corporate responses to climate change and stock performance: An international empirical analysis. Energy Econ. 2011, 33, 1283-1294. [CrossRef]

48. Brzeszczyński, J.; McIntosh, G. Performance of portfolios composed of British SRI stocks. J. Bus. Ethics 2014, 120, 335-362. [CrossRef]

49. Berkman, H.; Yang, W. Country-level analyst recommendations and international stock market returns. J. Bank. Financ. 2019, 103, 1-17. [CrossRef]

50. Sharpe, W.F. Capital asset prices: A theory of market equilibrium under conditions of risk. J. Financ. 1964, 19, 425-442. [CrossRef]

51. Lintner, J. The valuation of risk assets and the selection of risky investments in stock portfolios and capital budgets. Rev. Econ. Stat. 1965, 47, 13-37. [CrossRef]

52. Jensen, M.C. The performance of mutual funds in the period 1945-1964. J. Financ. 1967, 23, 389-416. [CrossRef]

53. Titman, S.; Wei, K.C.J.; Xie, F. Capital Investment and Stock Returns. J. Financ. Quant. Anal. 2004, 39, 677-700. [CrossRef]

54. Novy-Marx, R. The other side of value: The gross profitability premium. J. Financ. Econ. 2013, 108, 1-28. [CrossRef]

55. Fama, E.F.; French, K.R. International tests of a five-factor asset pricing model. J. Financ. Econ. 2017, 123, 441-463. [CrossRef]

56. Foye, J. A comprehensive test of the Fama-French five-factor model in emerging markets. Emerg. Mark. Rev. 2018, 37, 199-222. [CrossRef]

57. Mohanty, S.S. Does one model fit all in global equity markets? Some insight into market factor based strategies in enhancing alpha. Int. J. Financ. Econ. 2019, 24, 1170-1192. [CrossRef] 
58. Bauer, R.; Otten, R.; Rad, A.T. Ethical investing in Australia: Is there a financial penalty? Pac.-Basin Financ. J. 2006, 14, 33-48. [CrossRef]

59. Mateus, I.B.; Mateus, C.; Todorovic, N. UK equity mutual fund alphas make a comeback. Int. Rev. Financ. Anal. 2016, 44, 98-110. [CrossRef]

60. Angelidis, T.; Giamouridis, D.; Tessaromatis, N. Revisiting mutual fund performance evaluation. J. Bank. Financ. 2013, 37, 1759-1776. [CrossRef]

61. Campbell, J.; Shiller, R. The dividend-price ratio and expectations for future dividends and discount factors. Rev. Financ. Stud. 1988, 1, 195-228. [CrossRef]

62. Fama, E.F.; French, K.R. Dividend yields and expected stock returns. J. Financ. Econ. 1988, $22,3-27$. [CrossRef]

63. Fama, E.F.; French, K.R. Business conditions and the expected returns on stocks and bonds. J. Financ. Econ. 1989, 25, 23-49. [CrossRef]

64. Herold, U.; Maurer, R. Tactical asset allocation and estimation risk. Financ. Mark. Portf. Manag. 2004, 18, 39-57. [CrossRef]

65. Basiewicz, P.G.; Auret, C.J. Feasibility of the Fama and French three factor model in explaining returns on the JSE. Invest. Anal. J. 2012, 39, 13-25. [CrossRef]

66. Beller, K.R.; Kling, J.L.; Levinson, M.J. Are industry stock returns predictable? Financ. Anal. J. 1998, 54, 42-57. [CrossRef]

67. Chong, J.; Phillips, G.M. Sector rotation with macroeconomic factors. J. Wealth Manag. 2015, 18, 54-68. [CrossRef]

68. Morse, D. An econometric analysis of the choice of daily versus monthly returns in tests of information content. J. Account. Res. 1984, 22, 605-623. [CrossRef]

69. Brown, S.J.; Warner, J.B. Using daily stock returns: the case of event studies. J. Financ. Econ. 1985, $14,3-31$. [CrossRef]

70. Campbell, J.; Lo, A.; MacKinlay, C. The Econometrics of Financial Markets; Princeton University Press: Princeton, NJ, USA, 1997.

71. Bessler, W.; Wolff, D. Do commodities add value in multiasset portfolios? An out-of-sample analysis for different investment strategies. J. Bank. Financ. 2015, 60, 1-20. [CrossRef]

72. Sortino, F.; Satchell, S.E. Managing Downside Risk in Financial Markets: Theory, Practice and Implementation; Butterworth-Heinemann: Oxford, UK, 2001.

73. Sortino, F. The Sortino Framework for Constructing Portfolios Focusing on Desired Target Return ${ }^{\mathrm{TM}}$ to Optimize Upside Potential Relative to Downside Risk; Elsevier: Oxford, UK, 2009.

74. DeMiguel, V.; Garlappi, L.; Uppal, R. Optimal Versus Naive Diversification: How Inefficient is the 1/N Portfolio Strategy? Rev. Financ. Stud. 2009, 22, 1915-1953. [CrossRef]

75. Fama, E.F.; MacBeth, J.D. Risk, return, and equilibrium: Empirical tests. J. Political Econ. 1973, 81, $607-636$. [CrossRef]

76. Griffin, J.M. Are the Fama and French factors global or country specific? Rev. Financ. Stud. 2002, 15, 783-803. [CrossRef]

77. Mishra, S.; DeFusco, R.A.; Prakash, A.J. Skewness preference, value and size effects. Appl. Financ. Econ. 2008, 18, 379-386. [CrossRef]

78. Barth, M.E.; Konchitchki, Y.; Landsman, W.R. Cost of capital and transparency. J. Account. Econ. 2013, 55, 206-224. [CrossRef]

79. Verheyden, T.; De Moor, L.; Vanpée, R. Mutual fund performance: A market efficiency perspective. Invest. Anal. J. 2016, 45, 1-15. [CrossRef]

80. Zeng, Y. Institutional investors: Arbitrageurs or rational trend chasers. Int. Rev. Financ. Anal. 2016, 45, 240-262. [CrossRef]

81. Blitz, D.; Huij, J. Evaluating the performance of global emerging markets equity exchange-traded funds. Emerg. Mark. Rev. 2012, 13, 149-158. [CrossRef]

(C) 2020 by the authors. Licensee MDPI, Basel, Switzerland. This article is an open access article distributed under the terms and conditions of the Creative Commons Attribution (CC BY) license (http://creativecommons.org/licenses/by/4.0/). 